\title{
The Quality of Stakeholder Engagement in Sustainability Reporting: Empirical Evidence and Critical Points
}

\author{
Giacomo Manetti* \\ Assistant Professor in Financial Accounting - Department of Business Administration - \\ University of Florence - 50127 Firenze, Italy
}

\begin{abstract}
The aim of the article is to investigate the quality of stakeholder engagement (SE) in sustainability reporting (SR). The first part analyses the role of SE in SR according to the literature: SE is a fundamental step of the reporting process because of its role in defining materiality and relevance of the information communicated. The second part of the paper is dedicated to an empirical analysis of a sample of sustainability reports. The analysis showed that what is really applied in a wide majority of the cases is a stakeholder management approach rather than an SE approach. In the light of the above, questions for the future are if SE is moving from being a simple way to consult and influence stakeholders to an effective instrument for involving them in the company's decision making, through a mutual commitment. Copyright (c) 2011 John Wiley \& Sons, Ltd and ERP Environment.
\end{abstract}

Received 17 June 2009; revised 18 November 2010; accepted 24 November 2010

Keywords: stakeholder engagement; sustainability reporting; Global Reporting Initiative; stakeholder theory; materiality; content analysis

\section{Introduction}

T

HE STAKEHOLDER THEORY HAS BEEN AT THE CORE OF THE SCIENTIFIC DEBATE IN MANAGEMENT AND ACCOUNTING studies for over twenty years after the first formulation of the 'stakeholder approach' by Freeman (I984).

If the relationship between the stakeholder and the corporation was originally conceived following a 'hub and spoke' approach, in the last decade models of interactive relations (stakeholder thinking) were developed, in which the management and stakeholders agree to a management approach oriented towards transparency and accountability (Andriof et al., 2002, p. 9).

Particularly, stakeholder theory scholars have tried to classify the relational models between corporations and stakeholders assuming a gradual growth path of the stakeholders' involvement that includes the following phases (Svendsen, I998; Waddock, 2002):

- In a first stage of the relationship, corporations identify their stakeholders (stakeholder mapping), if possible distinguishing between primary (which determine the very survival of the corporation) and secondary (that affect or are affected by the corporation but do not affect its sustainability) (Clarkson, I995).

*Correspondence to: Giacomo Manetti, Department of Business Administration - University of Florence - Via della Pandette, 9 - 50127 Firenze. E-mail: giacomo.manetti@unifi.it 
- Secondly, the corporations try to manage stakeholders' expectations and the social and economic issues that they support, balancing the positions (stakeholder management).

- In a last phase, called stakeholder engagement (SE), corporations involve their stakeholders in decision-making processes, making them participants in the business management, sharing information, dialoguing and creating a model of mutual responsibility.

A main question in stakeholder management is the identification and prioritization of stakeholders (Clarkson, I995; Donaldson and Preston, I995; Carroll, I996). Mitchell et al. (I997) proposed a framework that categorized stakeholders in terms of power, legitimacy, and urgency, so that the more of these attributes a stakeholder has, the more salient the stakeholder is, defined in terms of managerial attention. The ability to manage stakeholder groups is also strongly associated with satisfaction with corporate social responsibility (Sangle, 20Io).

The SE phase, unlike the first two, foresees a mutual commitment on resolving issues that may emerge in the relations between the corporation and its general and specific environment. SE is therefore a process that 'creates a dynamic context of interaction, mutual respect, dialogue and change, not a unilateral management of stakeholders' (Andriof et al., 2002, p. 9).

According to Phillips (I997), SE is based on the 'moral' assumption that the firm has an obligation to its stakeholders: 'Stakeholder status as here conceived indicates the presence of an additional obligation over and above that due others simply by virtue of being human' (Phillips, I997, p. 83).

For the author, in ideal conditions the involvement draws on a cooperative scheme called a 'mutually beneficial and just scheme of cooperation' (Phillips, I997, p. 54), which is based on the idea of 'social contract' (Rawls, I97I). The concept of reciprocity of rights and duties implies overcoming a vision focused on the interests of shareholders, alleging that stakeholder expectations are managed in an instrumental and strategic manner for the creation of worth in the medium to long term (Jonker and Foster, 2002).

In this perspective, relations between stakeholders and corporations are based on the principles of reciprocity, interdependence, and power (Andriof and Waddock, 2002, p.I9) as a network that interprets the relationship as two-way rather than one-way (Rowley, I997).

The main feature of SE, therefore, is not the mere involvement of stakeholders to 'mitigate' or manage their expectations (stakeholder management), but to create a network of mutual responsibility (Andriof et al., 2002, p. I5). Stakeholders are also participants in business management through the submission of questions and issues deemed important that generate positive or negative impact on corporations, influencing managerial decisions. Their main responsibility is therefore to avoid making matters that might cause unintended negative externalities on the corporation, other organizations or local communities (Andriof et al., 2002, p. I5; Windsor, 2002, p. 138). If, on the contrary, the negative effects of the mentioned subjects were known and based on ethical relevant issues, stakeholders would still have fulfilled their fiduciary duties to the company.

As a conclusion, if stakeholders have responsibilities and rights, then their interest in the relationship with the corporation goes beyond the scope of mere satisfaction of their ambitions and expectations. In other words, their interest is also what they have with the corporation and the other partners with whom they interact. Stakeholders, therefore, as petitioners with legitimate expectations, assume the role of moral agents (Jones et al., 2002) with the responsibility to consider the rights and interests of the corporation and of the other parties and promote effective and ethically correct relationships (Wicks and Goodstein, 2009, p. I5).

Inspired by these considerations, the purpose of this study is to understand the role that $\mathrm{SE}$ takes in the process of social and sustainability reporting (SR), including consideration of the dual-way that should characterize, in theory, relations between corporations and stakeholders.

In particular, it wants to determine whether and to what extent SE is effective or rather tends to assume the characteristics of stakeholder management and a balancing of different expectations (Owen et al., 200I).

Assuming that corporations oriented towards good practices of corporate social responsibility (with particular reference to reporting) implement policies of involvement characterized by mutual and bi-univocal relations with their stakeholders, in the following sections we:

- discuss the role of SE in social reporting and sustainability (understood both as process and product) with particular reference to the principles of materiality and relevance of information disclosed; 
- analyze the management implications, with particular reference to corporate governance, of a proper application of SE (Welford, 2007; Prado-Lorenzo et al., 2009; Spitzeck and Hansen, 2010);

- identify the criticality points of SE and the tools that can be concretely implemented to ensure participation of stakeholders in corporate decision-making processes, proposing a measurement model of their involvement;

- undertake empirical research on a sample of sustainability reports of multinational corporations, to check in these documents the features of the engagement undertaken and also highlight the cases in which the involvement directly concerns the corporate governing bodies; and

- come to a conclusion on the state of the art, giving, compared to the proposed model, the current propensity of corporations to involve stakeholders.

\section{The role of stakeholder engagement in sustainability reporting}

According to the accounting literature, SR has been used by corporations as a legitimating tool to change the expectations of stakeholders (Swift, 200I; Campbell, 2003), although this has often been found ineffective (O' Dwyer, 2002).

Despite this, the principle of relevance and materiality in the context of SR foresees that SE will determine which information and data should be included in the report (Gray, 2000).

Main international standards and guidelines for SR and assurance require SE as a compulsory stage to get a complete and useful document for the intended users (AccountAbility, I999; 2003; 2005; Global Reporting Initiative, 2006).

In fact, more than giving a general framework of corporation activities as planned and carried out by managers, an environmental and social report should communicate really useful information for stakeholders (Global Reporting Initiative, 2006).

In the last decade, much research, both at national and international levels, collected empirical evidence of unprecedented levels of stakeholder dialogue in SR, but it questioned the sincerity and the impact of these practices on sustainability reports (UNEP and SustainAbility, I999; Downey, 2002; Miles et al., 2002).

It found that engagement and dialogue with stakeholders are increasingly recognized as crucial elements of SR, although conceding that there is a shortage of evidence within social and environmental reports that such engagement and dialogue is actually taking place (ACCA, 2005).

The quality of SE can be measured and evaluated, according to the literature, through a series of elements and factors that should be critically analyzed.

For example, Strong et al. (200I) suggest three critical factors for stakeholder satisfaction: timeliness of communication, honesty and completeness of information, and empathy and equity of treatment by managers.

Zöller (I999) asserts that effective dialogues require symmetrical communication, transparency of the benefits and risks, unbiased facilitation, inclusivity, and an early start to facilitate change if needed.

Zadek and Raynard (2002) suggest three dimensions for quality: procedural quality (how the engagement was undertaken and whether it was consistent with the declared purposes), responsiveness quality (how the organization answers to the stakeholder needs), and the quality of outcomes (tangible evidence of policies and practices adopted by managers in line with SE or evidence of stakeholder satisfaction).

Friedman and Miles (2006) present a model of SE evaluation that is intended to illustrate degrees of the quality of stakeholder management from the stakeholders' perspective. The model is based on Arnstein's Ladder of Citizen Participation (I969) that conceptually represents the degree of power given to citizens in community decisions, ranging from a paternalistic to a more participatory system. The ladder comprises eight categories:

- I and 2. Manipulation and Therapy: These first two levels refer to the control, skilful management, or manoeuvring of stakeholders' opinion. In this context, managers try to brainwash stakeholders through intensive bombardment of self-laudatory corporate information until they are indoctrinated with the same principles of the corporation.

- 3, 4, and 5. Informing, Consultation, and Placation: The emphasis is either on a one-way flow of information or, where there is two-way communication, the received views may not be used or acted on. Managers maintain the right of decision and veto. 
- 6. Partnership: At this level stakeholders are involved in planning and in the decision-making processes.

- 7. Delegated power: Stakeholders have sufficient decision-making authority and the intention of the engagement is minority representation of stakeholders in decision-making process through multiway dialogue, such as board representation.

- 8. Citizen control: Stakeholders obtain the majority of decision-making seats or full managerial power in an organization.

With reference to the application of Arnstein's Ladder of Citizen Participation to sustainability reports, Cumming (200I) notes that, in her sample of I3 British or multinational companies, managers reported that approaches to stakeholder dialogue are mixed and matched depending on the stakeholder groups concerned, their physical location, and the relevant issue.

Cumming conducts her research using semi-structured interviews with directors of functional areas or CEOs of the corporations included in the sample.

The author uses the following criteria:

- Where structured enquiries and research are employed (using techniques borrowed from marketing) to monitor the opinions and expectations of company stakeholders, we have levels 3 and 4 of Arnstein's Ladder.

- When panels or small groups of stakeholder representatives have been nominated, (e.g. focus groups, round tables, community forums) that 'have dialogue' with management, we have reached levels 5 and 6 of the Ladder.

- When consultation techniques are applied, such as telephone interviews, one-to-ones and dedicated hotlines, the company is rated between levels 4 and 6 .

The author points out that, in the vast majority of cases in the companies studied, SE is limited to levels I-5 on the Arnstein's Ladder. Her research identified only one case of partnership (level 6) using bi-directional communication and no companies at all on levels 7 and 8.

Cumming emphasis that the higher levels of the Ladder cannot be found in the sample, owing to the problem of balancing different expectations among stakeholders. In particular, to reach the eighth level, companies would have to redefine their statutes, sometimes violating the principal that is commonly found in company law of safeguarding, as a priority, the investors and shareholders.

As far as the seventh level is concerned, only companies particularly inclined towards good social responsibility practices could envisage delegating decision-making to stakeholders.

Given the above, the aim of our research is to verify the quality of SE in SR with particular reference to the involvement of stakeholders in decision-making processes and the creation of a mutual responsibility model.

We aim also to verify the conclusions stated by Cumming in her empirical study using Arnstein's Ladder of Citizen Participation.

\section{Method}

A sample was studied of I74 sustainability reports in English, Spanish or in Portuguese, drawn up according to the Sustainability Reporting Guidelines version 3.0 issued by the Global Reporting Initiative (GRI). We collected, as of 3I December 2009, all the 2008 reports in the GRI online database with level «A+ GRI checked».

This is the maximum level of accordance with guidelines and it involves:

- reporting on all indicators and other numbered elements required by G3 (level A);

- an assurance service by an external independent auditor (marked by + ); and

- a formal check of the report contents by GRI.

This means that these reports represent best practices in SR worldwide; furthermore, GRI guidelines foresee for level A, a compulsory section on SE policies and practices implemented by the corporation in the reporting process to define the materiality and the relevance of the information published. To verify the level of SE, this 
aspect and the information reported in the paragraph on the governing bodies have been specially taken into account.

These two sections include information on:

- Stakeholder groups engaged by the organization.

- Basis for identification and selection of stakeholders with whom to engage. This involves the organization's process of defining its stakeholder groups and determining which groups to engage with or not.

- Approaches to SE, including frequency of engagement by type and by stakeholder group. This could comprise surveys, focus groups, community panels, corporate advisory panels, written communication, management/ union structures and other means. The organization should indicate whether any of the engagement was undertaken specifically as part of the report preparation process.

- Key topics and concerns that have been raised through SE and how the organization has responded to them, including through its reporting.

- If appropriate, the indication of representatives of stakeholders' categories appointed to governing bodies.

The I74 statements refer to a sample of companies whose characteristics are listed in Table I.

The majority of the companies are from Europe (74\%), are medium or large $57 \%$ over 5000 employees), are quoted on the Stock Exchange (67\%), and operate in the financial services (29\%) or in the energy $(26 \%)$ sectors.

\begin{tabular}{|c|c|c|}
\hline BUSINESS CATEGORIES & N. & $\%$ \\
\hline Financial services & 51 & $29.31 \%$ \\
\hline Energy and energy utilities & 45 & $25.86 \%$ \\
\hline Construction and building materials & 16 & $9.20 \%$ \\
\hline Healthcare services and products & 9 & $5.17 \%$ \\
\hline Telecommunications & 6 & $3.45 \%$ \\
\hline Logistics & 6 & $3.45 \%$ \\
\hline Chemicals & 4 & $2.30 \%$ \\
\hline Automotive & 3 & $1.72 \%$ \\
\hline Computers & 3 & $1.72 \%$ \\
\hline Conglomerates & 3 & $1.72 \%$ \\
\hline Other sectors & 28 & $16.09 \%$ \\
\hline Total & 174 & $100.00 \%$ \\
\hline \multicolumn{3}{|l|}{ COUNTRY } \\
\hline Europe & 128 & $73.56 \%$ \\
\hline North America & 6 & $3.45 \%$ \\
\hline South America & 22 & $12.64 \%$ \\
\hline Australia & o & $0.00 \%$ \\
\hline Asia & 18 & $10.34 \%$ \\
\hline Total & 174 & $100.00 \%$ \\
\hline \multicolumn{3}{|l|}{ DIMENSION (number of employees) } \\
\hline $0-5000$ & ו & $40.80 \%$ \\
\hline $5001-10000$ & 29 & $16.67 \%$ \\
\hline $10001-30000$ & 28 & $16.09 \%$ \\
\hline $30001-80000$ & 18 & $10.34 \%$ \\
\hline over 80000 & 28 & $16.09 \%$ \\
\hline Total & 174 & $100.00 \%$ \\
\hline \multicolumn{3}{|l|}{ QUOTED ON STOCK EXCHANGE } \\
\hline Yes & 117 & $67.24 \%$ \\
\hline No & 57 & $32.76 \%$ \\
\hline Total & 174 & $100.00 \%$ \\
\hline
\end{tabular}

Table 1. Characteristics of the sample 
In stakeholder theory literature, little attention has been paid to the qualitative properties of information stated in sustainability reports regarding SE policies and practices. We believe that, in analyzing SE disclosure, attention has to be paid both to the presence of an SE section and also to its intrinsic characteristics of what has been disclosed and how.

The method chosen for the analysis of SE disclosure is content analysis. It is a method widely adopted in corporate disclosure studies (Guthrie et al., 2004) because it allows repeatability and valid inferences from data according to their context (Krippendorff, I980).

Three researchers conducted the analysis: two PhD students and an assistant professor.

On the basis of the research questions mentioned above, a list of detection and classification rules was defined and discussed with researchers and classification criteria for each dimension of the research questions were subsequently identified. Afterwards, a preliminary test of the coding procedure was conducted to highlight ambiguous or unclear coding rules and to standardize the classifying capabilities of the researchers: three 2007 sustainability reports of companies included in the GRI database, checked at level A+ GRI, were independently examined by the three researchers. The results of the individual classification were compared and the differences discussed. This preliminary activity resulted in a final set of detection and classification rules. Using this, another 2007 sustainability report was coded by all research members to test the alignment of the research team on the coding procedure.

Attention was also given to possible additional elements such as difficulties met in the SE and future improvements in the social reports' structure and content.

\section{Results}

Research questions and results from the sample are shown in Table 2.

In all cases analyzed, SE was presented as an unavoidable element of companies' social commitment. However, a proper section was not always devoted to this issue. In fact, in $14 \%$ of cases, the description of SE policies and practices has been inferred from the whole report.

Furthermore, it was observed that SE was interpreted in different ways. We made an attempt to identify its major objectives as emerging from the investigated reports. Those purposes have been grouped into four categories:

I. Setting or reviewing strategic objectives.

2. Setting the content of the report (defining what information is relevant).

3. Both of the previous elements.

4. No reference to the previous elements.

Analyzing the sections dedicated to SE, we noted that in $38 \%$ of cases, the relationship built with stakeholders aimed at involving them in fixing or reviewing the strategic objectives of the corporation. In this perspective, stakeholder participation in the company's social and environmental accounting is important for the definition of sustainable strategic goals, or in getting advice on present strategies which then will be modified accordingly. Stakeholders were supposed to express opinions on the accomplishment of the sustainable strategic objectives and on the consistency of managerial activities but not on the content of the report. The information communicated in the report could be hardly defined 'material' or 'relevant' because it is not an output of a consultation process and it doesn't involve stakeholder dialogue.

In only $20 \%$ of cases we noted that the aim of stakeholders' involvement was to decide the content of the report or both to decide information supposed relevant and to elaborate (or to review) strategic objectives. The thesis could be put forward that the information disclosed is reasonably relevant and material, but it would be necessary to collect more information from the organization.

In 73 cases $(42 \%)$ there is no reference to the previous elements. Actually, in these reports, there is a lack of information on the strategic objectives and on the stakeholder needs and opinions. These SE sections seem very 
1. GENERAL INFORMATION

1.1. Has a proper section been devoted to the SE in the report?

Yes

$\begin{array}{rr}149 & 85.63 \% \\ 25 & 14.37 \% \\ 174 & 100.00 \% \\ & \\ 66 & 37.94 \% \\ 18 & 10.34 \% \\ 17 & 9.77 \% \\ 73 & 41.95 \% \\ 174 & 100.00 \%\end{array}$

2. DEGREE OF REPRESENTATION OF STAKEHOLDER

$100.00 \%$

1.2. Aims and objectives of SE

- setting or reviewing strategic objectives

- setting the content of the report (defining what information are relevant)

- both of the previous elements

- no reference to the previous elements

2.1. Have all the stakeholders identified in the report been engaged?

Yes

$149 \quad 85.63 \%$

No

2.2. Among the groups engaged, have representatives been appointed?

Yes

No

3. DEGREE OF STAKEHOLDER INVOLVEMENT

$174 \quad 100.00 \%$

3.1. Simple consultation, monitoring, and information gathering?

Yes

$128 \quad 73.56 \%$

No

$46 \quad 26.44 \%$

3.2. Direct involvement in the reporting process?

$174 \quad 100.00 \%$

Yes

$55 \quad 31.61 \%$

No

$119 \quad 68.39 \%$

$174 \quad 100.00 \%$

3.3. Proactive role and appointment of representatives in the governing bodies?

Yes

$\begin{array}{rr}27 & 15.52 \% \\ 147 & 84.48 \% \\ 174 & 100.00 \%\end{array}$

3.4. Preventive engagement accomplished in the earlier stages of planning and accounting (information gathering) or stakeholders are addressed to review the final document ready to be released?

- only preventive

- only final

$\begin{array}{rr}68 & 39.09 \% \\ 53 & 30.46 \% \\ 35 & 20.11 \% \\ 18 & 10.34 \% \\ 174 & 100.00 \%\end{array}$

3.5. Is there stakeholders' perception on the previous edition of the sustainability report?

- both

- not declared

Yes

$103 \quad 59.20 \%$

No

first report

3.6. If so, are stakeholders required to express their opinion on the materiality and reliability of the information displayed?

Yes

$35 \quad 20.12 \%$

No

there is no perception of previous report

4. ENGAGEMENT CHANNELS AND METHODS

$174 \quad 100.00 \%$

4.1. Are the channels and methods used to reach the stakeholders identified?

Yes

No 


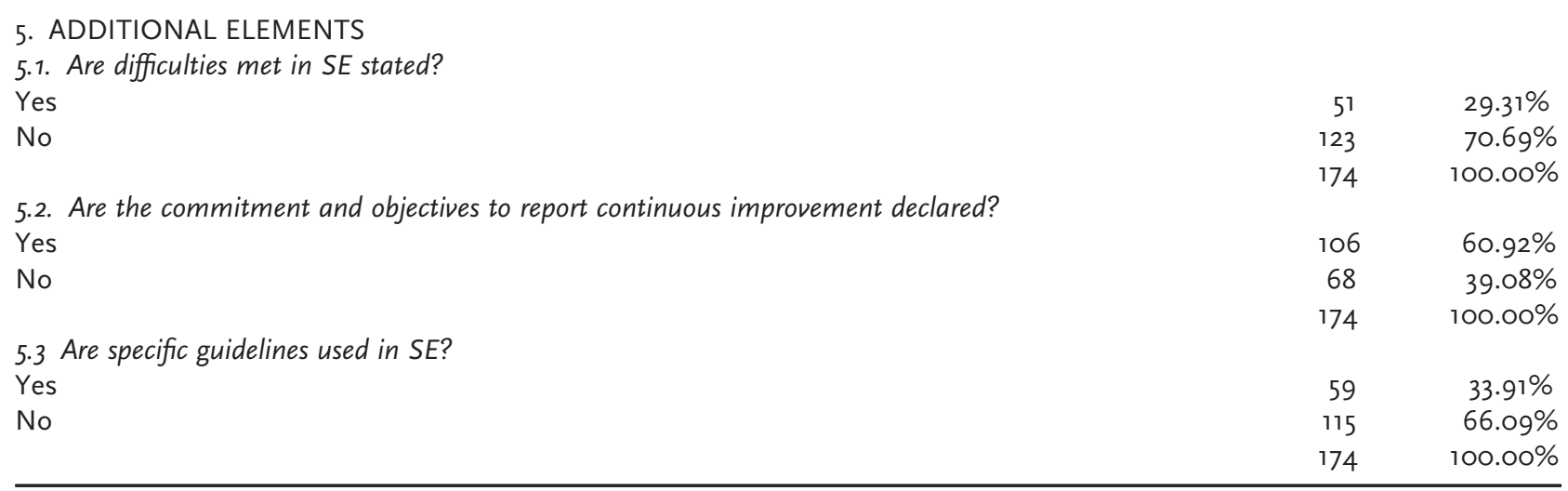

Table 2. Research questions and results

often 'self-laudatory' and 'specious gloss' attempts to cover, through 'blue-washing' policies, antisocial or environmentally harmful actions (Zadek et al., I997).

The above-described analysis led us to examine the stakeholders identified in the sustainability reports and, specifically, those who were currently engaged by the organization.

In $86 \%$ of the cases, all listed stakeholders had been involved in the SE process. In the other cases, there were groups left aside, although no group remained constantly uninvolved by the majority of the companies. On the contrary, it can be stated that there were categories always engaged, such as shareholders and employees, but the content analysis is not sufficient to clarify the level of engagement, because the language and the expressions used are subject to interpretation.

In $22 \%$ of the cases, it was observed that representatives of the various groups engaged had actually been appointed by the group itself, to deal with the organization. In the majority of these corporations, the representatives were members of an ethics committee established ad hoc. Only in few cases (9) was the selection criterion mentioned and it was the representation of two categories (employees and local community) that had to be compulsorily engaged according to the law.

With reference to the degree of stakeholder involvement, it was found that in almost three-quarters of the cases (74\%) SE implies only advising, monitoring, and information gathering. Therefore, stakeholders had been addressed just to get the information needed for the reporting and to get their opinions on the reliability, materiality, and relevance of those data. In other words, in these reports the disclosure on SE shows that stakeholders had only an advisory role.

In almost one-third of the cases (32\%) the research team found explicit information on direct involvement of stakeholders in the reporting process. Therefore, their engagement was important not only to gather the relevant information to be displayed in the document, but also to get them to actively participate in the whole reporting process.

This means that in these reports, stakeholders had an active role in selecting the information to express in the document so that they operated as real decision makers.

In a few cases (15\%), the involvement turned into an actual proactive participation through membership of stakeholders' representatives in the company's governing bodies. In these companies very often we found laws that required the appointment of representatives of stakeholders in the governing bodies. For example, the Spanish savings banks (Caja de Ahorros) present in the GRI database are private foundations with no capital representation but with a social purpose. In these entities the law foresees a direct presence of stakeholders in the General Assembly and in the Board of Administration. A 2007 research showed that in these governing bodies mainly sit representatives of customers, municipalities, founders, and, to a lesser degree, of employees, general interest organizations and regional governments (Vélaz et al., 2007; Prado-Lorenzo et al., 2009). 
A different situation, but with a significant representation of employees in the governing bodies, can be found in the German corporations contained in the database, because they follow the well-known legal framework of codetermination (Mitbestimmung).

With reference to the timing of the engagement, in 59\% of the cases SE was preventive or both preventive and final, since it is as important to collect the information relevant to the content of the report, as to better accomplish the reporting process. In $30 \%$ of the reports, the aim of SE was to obtain opinions on the report ready to be issued (engagement before the publication). In these cases, stakeholders were required to state their views on the reliability, materiality, and relevance of the report but they didn't have the possibility to change the reported data.

In $59 \%$ of the companies, stakeholders were even asked to outline their views on the previous edition of the report. Their opinions referred either to the content or the structure of the document:

- Comments on the content related to the need of more information and detail in certain areas of the report.

- Comments on the structure concerned the need of adding other important areas in the sustainability report.

Moving from the specific analysis of the degree of SE in the reporting process, the survey was extended to the channels and methods used to involve them.

These channels and methods were analyzed both for SE aimed at involving stakeholders in the strategic planning process and for SE accomplished in the reporting process. The companies analyzed had used a variety of channels and methods to approach their stakeholders. From the content analysis we found that stakeholders were reached through channels such as the Internet, electronic mail, ordinary mail, press, telephonic contacts, and direct meetings. Only in $7 \%$ of the cases channels and methods were not specified in the SE disclosure.

Using those instruments, stakeholders express their opinions or participate in the decision-making process through surveys, focus groups, online forums, road shows, panels, public meetings, conferences, workshops, partnerships, one-to-one conversations, and talking to local representatives.

The final part of the research focused on the analysis of the following elements:

- Difficulties found in SE.

- Objectives of continuous improvement.

- Indication of specific guidelines used for SE.

In $29 \%$ of the reports, difficulties in SE were stated. Those difficulties were specifically linked to the problem of balancing the interests of different categories of stakeholders or inside a specific category. Furthermore, we never found a corporation that explicitly declared an order of priority in the engagement between the different categories. In other words, all the groups were considered at the same level of relevance and importance with reference to the SR process.

In $61 \%$ of the cases, the commitment to continuously improve the report's structure and content through better SE policies and practices was found. Usually this is associated with suggestions coming from stakeholders' perception of the previous edition of the sustainability report.

Finally, about one-third of the corporations (34\%) declared that SE has been carried out according to specific guidelines. In the documents analyzed, the guidelines were represented by national standards or by the international standard AAıooo SE issued by AccountAbility (2005).

\section{Conclusions}

In the majority of sample cases, $\mathrm{SE}$ is considered an essential element of reporting in conformity with international literature and practice. Nonetheless, our review of the literature (apart from Cumming's research mentioned above) indicates that no empirical analyses have verified the quality of this process. For this reason, the main objective of our research has been to investigate SE quality.

However, for many reports, even using certified translations, content analysis - unless used along with other research tools - does not permit us to verify if SE was implemented effectively. 
Furthermore, in the vast majority of companies, there are no stakeholders nominated from government bodies. Management adopts a decidedly rhetorical type of language, lacking in concrete indications on negative externalities produced, in an attempt to pursue its aims of self-legitimization. Here, it should be considered that a large part of sampled companies operate in sectors of high social or environmental impact.

Referring to the SE evaluation model proposed both by Cumming and by Friedman and Miles, based on Arnstein's Ladder of Citizen Participation, and on the basis of evidence gathered by our research team, it appears the delegation of decision-making power to stakeholders in the companies studied was significant but not decisive.

In fact, content analysis of the majority of reports suggests that the first five levels of the Ladder were reached. This conclusion is based in particular on the outcome of research questions in the third and fourth areas (respectively, degree of stakeholder engagement and engagement channels and methods).

Furthermore, in her 200I study, Cumming also associated the engagement tools and techniques used (market research, panels, interview) with the overall level of participation.

In any case, even leaving aside Cumming's criterion, our research shows that only on rare occasions, and only to comply with legal requirements, do we find examples of delegation of decisional power or even of citizen control (research question 3.3 and especially 3.4).

SE objectives, again in the majority of cases, were to promote a positive company image that comprised stakeholder consultation and the possibility of bi-directional communication. However the principal aim was to involve stakeholders in company management in order to placate or mitigate their requests, but without delegating any decisional power (see especially results of research questions: I.2, 3.I, 3.6, 5.I, 5.3).

A decidedly more advanced and incisive approach was taken by a minority of companies who undertook partnership with some stakeholder categories, involving their representatives in decision-making processes.

Even rarer situations were encountered of delegation of decisional power through a multiway type of dialogue. This was the case, already mentioned, of that group of Spanish and German companies, which explicitly required by law, nominate representatives of some stakeholder categories on their Boards. The main difference between these two cases is that for German companies, the legal principle of codetermination provides for a minority presence of a certain stakeholder category (employees) on the Supervisory Board. This grants significant (not dominant) influence to the category, which allows these companies to reach the seventh level of Arnstein's Ladder, entitled 'delegated power'.

By contrast, in the Spanish savings banks (Caja de Ahorros), stakeholders have majority representation at top management level. Here we have dominant influence by stakeholders, which corresponds to the eighth level of the Ladder (citizen control). In the interests of precision, however, it must be pointed out that even in these apparently 'multistakeholder' companies, the democratic nature of designation is often difficult to verify using simple content analysis. It is always possible, in fact, that the nominations are effectively co-options, rather than recognition of freely elected representatives from the various categories - especially considering the ample license allowed by law.

As far as the definition of SE is concerned and going back to our introductory comments, it is possible to reach some conclusive results that represent a generalization, in need of further analysis, of research findings.

In particular, factors such as:

- low stakeholder involvement in defining contents of reports (research questions 3.2 and 3.4);

- lack of nomination of representatives from the various categories (2.2);

- except where required by law, the rare presence in management bodies of categories not directly emanating from shareholders (3.3);

- lack of objective public judgement as to the materiality and relevance of information in the report (3.6); and

- rare adoption of guidelines or standards on engagement by the companies analyzed (5.3)

are all compelling elements that indicate prevailing practices of stakeholder management, rather than of any real engagement (Svendsen, I998; Waddock, 2002).

Therefore, we conclude that present SR practice, as revealed by this research, does not implement the ideal of SE; rather corporations are seen to be using it as a legitimization device and for managing the stakeholders effectively (for similar conclusions, see also Belal, 2002). 
The propensity for stakeholder management, rather than SE, matches an opportunistic and strategic approach to the stakeholder theory (Freeman, I984), since management believes it essential to involve stakeholders in order to reach a social consensus necessary for economic success in the long term (Hart and Sharma, 2004), without acknowledging their legitimate interest (Evan and Freeman, I988).

Our study has found a reasonable number of companies who, partly because of legal obligations, are placed firmly on the seventh and eighth levels of the Ladder. But there is also a broad majority of companies which appears to use SE in an opportunistic way to obtain consensus from their local community. This situation is confirmed by the large number of documents where certain recurring categories of stakeholders are quite evidently excluded from engagement - particularly suppliers, public administrations, NGOs and lenders (with reference to the role of NGOs, see van Huijstee and Glasbergen, 2008).

Among the limits of the present study may be mentioned the substantial heterogeneity of the sample, connected with the initial choice to analyze all 'A+ GRI checked' companies, independent of factors such as structure of institution, dimension, relevant regulations, and industrial sector of operations.

In conclusion, the majority of companies analyzed are a long way from implementing an SE process in accordance with theories such as the 'two-way conversation' (Goodstein and Wicks, 2007), which creates a dynamic context of mutual respect and change (Andriof et al., 2002), with a cooperative scheme of collaboration and dialogue (Phillips, I997).

In this context, one possible development of research carried out to date would be to verify the perception stakeholders have of their involvement in company management, in order to evaluate their real interest in taking part in decisional processes of the company. Stakeholders have been traditionally viewed by companies as passive subjects with their own agenda; but in this sense, they are groups or individuals who, by means of a wide and diversified range of initiatives (lobbying and networking, ethical consumption, advocacy, and promotion of civil rights) can make an active contribution to raising awareness of businesses towards economic, social and environmental themes, connected with each stakeholder category.

In other words, one ought to verify if and to what extent companies and their stakeholders practice the concept of corporate citizenship (Matten and Crane, 2003), by which is meant:

- recognition by the company of all civil, social and political rights normally guaranteed to citizens (Matten et al., 2003); and

- the proactive role of businesses in guaranteeing and promoting civil rights of individuals and other institutions (Crane et al., 2005; Matten and Crane, 2005).

\section{Acknowledgment}

The author thanks Julia Campbell Hamilton (j.hamilton@email.it) for revision of the English version of this article and the two anonymous reviewers for their constructive comments.

\section{References}

ACCA. 2005. Improving Stakeholder Engagement Reporting: An ACCA and the Environment Council Workshop. Certified Accountants Educational Trust: London.

AccountAbility. I999. AA1000 Framework. AccountAbility: London.

AccountAbility. 2003. AA1000 Assurance Standard. AccountAbility: London.

AccountAbility. 2005. Stakeholder Engagement Standard. AccountAbility: London.

Andriof J, Waddock S, Husted B, Rahman S. 2002. Unfolding Stakeholder Thinking: Theory, Responsibility and Engagement. Greenleag Publishing: Sheffield; 9-16.

Andriof J, Waddock S. 2002. Unfolding stakeholder engagement. In Unfolding Stakeholder Thinking: Theory, Responsibility and Engagement, Andriof J, Waddock S, Husted B, Rahman S (eds). Greenleag Publishing: Sheffield; I9-42.

Arnstein SR. I969. A ladder of citizen participation. American Institute of Planners Journal 35: 216-224.

Belal AR. 2002. Stakeholder accountability or stakeholder management: a review of UK firms' social and ethical accounting, auditing and reporting (SEAAR) practices. Corporate Social Responsibility and Environmental Management 9: 8-25. 
Campbell D. 2003. Intra-and inter-sectorial effects in environmental disclosures: evidence for legitimacy theory? Business Strategy and the Environment 12: 357-37I.

Carroll AB. 1996. Business and Society-Ethics and Stakeholder Management. South-Western Publishing Co: Cincinnati.

Clarkson MBE. I995. A stakeholder framework for analyzing and evaluating corporate social performance. Academy of Management Journal 20: $92-118$.

Crane A, Driver C, Kaler J, Parker M, Parkinson J. 2005. Stakeholder democracy: towards a multi-disciplinary view. Business Ethics: A European Review I4: 67-75.

Cumming JF. 200I. Engaging stakeholders in corporate accountability programmes: a cross-sectoral analysis of UK and transnational experience. Business Ethics: A European Review Io: 45-52.

Donaldson T, Preston LE. I995. The stakeholder theory of the corporation: concepts, evidence and implications. Academy of Management Review 20: 65-92.

Downey PR. 2002. The essential stakeholder dialogue. Corporate Social Responsibility and Environmental Management 9: 37-45.

Evan W, Freeman R. I988. A stakeholder theory of the modern corporation: kantian capitalism. In Ethical Theory and Business, Beauchamp T, Bowie N (eds), 3rd ed, Vol 97. Prentice Hall: Englewood Cliffs (NJ); IOI-IO5.

Freeman RE. 1984. Strategic Management: A Stakeholder Approach. Pitman: Boston MA.

Friedman AL, Miles S. 2006. Stakeholders: Theory and Practice. Oxford University Press: Oxford.

Global Reporting Initiative. 2006. Sustainability Reporting Guidelines. G3 Version. GRI: Amsterdam.

Goodstein JD, Wicks AC. 2007. Corporate and stakeholder responsibility: making business ethics a two-way conversation. Business Ethics Quarterly I7: 375-398.

Gray R. 2000. Current developments and trends in social and environmental auditing, reporting and attestation: a review and comment. International Journal of Auditing 4: 247-268.

Guthrie J, Petty R, Yongvanich K, Ricceri F. 2004. Using content analysis as a research method to inquire into intellectual capital reporting. Journal of Intellectual Capital 5: 282-93.

Hart SL, Sharma S. 2004. Engaging fringe stakeholder for competitive imagination. Academy of Management Executive I8: 7-I8.

Jones TM, Wicks AC, Freeman RE. 2002. Stakeholder theory: the state of the art. In The Blackwell Guide to Business Ethics, Bowie NE (ed). Blackwell Publishers: Oxford; I9-37.

Jonker J, Foster D. 2002. Stakeholder excellence: framing the evolution and complexity of a stakeholder perspective of the firm. Corporate Social Responsibility and Environmental Management 9: I87-195.

Krippendorff K. I980. Content Analysis: an Introduction to its Methodology. Sage Publications: Beverly Hills CA.

Matten D, Crane A, Chapple W. 2003. Behind the mask: revealing the true face of corporate citizenship. Journal of Business Ethics 45: IO9-I20.

Matten D, Crane A. 2003. Corporate Citizenship: towards an Extended Theoretical Conceptualization. ICCSR Research Paper Series: Nottingham.

Matten D, Crane A. 2005. What is stakeholder democracy? Perspectives and issues. Business Ethics: A European Review I4: 6-I3.

Miles S, Hammond K, Friedman AL. 2002. ACCA Research Report No. 77: Social and Environmental Reporting and Ethical Investment. Certified Accountants Educational Trust: London.

Mitchell RK, Agle BR, Wood DJ. I997. Toward a theory of stakeholder identification and salience: defining the principle of who and what really counts. Academy of Management Review 22: 853-886.

O’Dwyer B. 2002. Managerial perceptions of corporate social disclosure: an Irish story. Accounting, Auditing and Accountability Journal I5: 406-436.

Owen D, Swift T, Hunt K. 200I. Questioning the role of stakeholder engagement in social and ethical accounting, auditing and reporting. Accounting Forum 25: 264-282.

Phillips R. I997. Stakeholder theory and a principle of fairness. Business Ethics Quarterly 7: 5I-66.

Prado-Lorenzo JM, Gallego-Alvarez I, García-Sánchez IM. 2009. Stakeholder engagement and corporate social responsibility reporting: the ownership structure effect. Corporate Social Responsibility and Environmental Management I6: 94-I07.

Rawls J. I97I. A Theory of Justice. Harvard University Press: Cambridge MA.

Rowley TJ. I997. Moving beyond dyadic ties: a network theory of stakeholder influences. Academy of Management Review 22: 887910.

Sangle S. 20I0. Critical success factors for corporate social responsibility: a public sector perspective. Corporate Social Responsibility and Environmental Management I7: 205-2I4.

Spitzeck H., Hansen EG. 20I0. Stakeholder governance: how stakeholders influence corporate decision making. Corporate Governance Io: 378-391.

Strong KC, Ringer RC, Taylor SA. 200I. The rules of stakeholder satisfaction (timeliness, honesty, empathy). Journal of Business Ethics 32: 219-230.

Svendsen A. I998. The Stakeholder Strategy: Profiting from Collaborative Business Relationships. Berett-Koehler: San Francisco CA.

Swift T. 200I. Trust, reputation and corporate accountability to stakeholders. Business Ethics: A European Review Io: I6-26.

UNEP, SustainAbility. I999. The Social Reporting Report. UNEP and SustainAbility: London.

Van Huijstee M, Glasbergen P. 2008. The practice of stakeholder dialogue between multinationals and NGOs. Corporate Social Responsibility and Environmental Management I5: 298-310.

Vélaz I, Sison AJG, Fontrodona J. 2007. Incorporating CSR and stakeholder management into corporate strategy: a case study of the CAN experience 2002-2006. Corporate Governance 7: 434-445. 
Waddock SA. 2002. Leading Corporate Citizens: Vision, Values, Value Added. Mc Graw-Hill: Boston MA.

Welford R. 2007. Corporate governance and corporate social responsibility: issues for Asia. Corporate Social Responsibility and Environmental Management I4: 42-51.

Wicks AC, Goodstein JD. 2009. Stakeholder responsibility and stakeholder commitment. Notizie di Politeia 93: 9-24.

Windsor D. 2002. Stakeholder responsibilities: lessons for managers. In Unfolding Stakeholder Thinking: Theory, Responsibility and Engagement, Andriof J, Waddock S, Husted B, Rahman S (eds). Greenleag Publishing: Sheffield; I37-I54.

Zadek S, Pruzan P, Evans R. I997. Building Corporate AccountAbility. Emerging Practices in Social and Ethical Accounting, Auditing and Reporting. Earthscan Publications: London.

Zadek S, Raynard P. 2002. Stakeholder engagement: measuring and communicating quality. Accountability Quarterly I9: 8-I7.

Zöller K. I999. Growing credibility through dialogue: experiences in Germany and the USA. In Greener Marketing: A Global Perspective on Greening Marketing Practice, M. Charter M, Polonsky MJ (eds). Greenleaf Publishing: Sheffield UK; I96-206. 